International Journal of Linguistics, Literature and Translation

ISSN: 2617-0299 (Online); ISSN: 2708-0099 (Print)

DOI: 10.32996/ijltt

Journal Homepage: www.al-kindipublisher.com/index.php/ijltt

\title{
Shadism from the Perspective of Intersectionality in Toni Morrison's The Bluest Eye
}

\author{
Ahmed Seif EddineNefnouf 8 (D) \\ PhD candidate, Szeged University, Szeged, Hungary \\ $\triangle$ Corresponding Author:Ahmed Seif EddineNefnouf, E-mail: ahmednefnouf@gmail.com
}

\begin{tabular}{ll}
\hline ARTICLE INFORMATION & ABSTRACT
\end{tabular}

Received: March19, 2021

Accepted: April18, 2021

Volume:4

Issue: 4

DOI: $10.32996 / i j l t .2021 .4 .4 .24$

\section{KEYWORDS}

Shadism intersectionality, discrimination, racism, gender
This paper aims to discuss shadism from a perspective of intersectionality and how people with a darker skin tone suffered particular forms of discrimination due to the issues of shadism and its interaction with the class, gender, age, ability, and race. Shadism has infused the black society for many centuries, hence outlined during slavery. Shadism is the discrimination against a person with a darker skin tone, typically among individuals of the same racial group. In The Bluest Eye, Toni Morrison describes how African American women and girls like Pecola are considered ugly by her family and the community due to her darker skin tone. in this research paper we are going to explore shadism and examine intersectionality theory like race, gender, sexuality and class, and their influence on dark-skinned black women, through the main character Pecola Breedlove. Using intersectionality theory to understand shadism helps to know that there are different ways a person could face oppression and domination. This paper gives a new vision of shadism which have been studied as amatter of racism, but throughout the intersectionality of the the identity component. The analysis shows that shadism is influenced by race and other aspects of intersectionality such as gender, race, age and ability, and other aspects of identity.

\section{Introduction}

Shadism is the unfair treatment of persons falling within the same racial class based on color. This paper studies Toni Morrison's novel The Bluest Eye and the stories of black women and young girls relating to the beauty standards established by white America as well as the role families and society play in their reactions to these standards. This chapter also analyses the intersectionality of race, gender, class, and other identity aspects and how they influence shadism. This work intends to analyze how the intersectionality categories like race, gender, and class are portrayed in the novel and how it relates to the problems of white beauty standards and self-loathing or self-hatred. I suggest that The Bluest Eye is an objection against the adoption of beauty as a universal and positive value. Toni Morrison proposes the construction of healthy and wholesome identities through the association with the tradition and culture of a society (Dittmer, 19). The aim is to begin by examining the ideas and objectives of the African American literary and black feminist movements during the time. Then, making an analysis of the characters in the novel. Instead of supporting the idea that blackness is beautiful, the novelist portrays that the characters become obsessed with beauty standards and acknowledged by the whites to the extent that they end up hurting others and themselves.

\section{Literature Review}

\section{What is done about intersectionality and racial issues in The Bluest Eye by Toni Morrison?}

Intersectional discrimination is a type of discrimination that occurs by multiple personal grounds, identities, or characteristics that function and associate with one another at the same time in a way that they cannot be separated. It happens when a person is discriminated against because of the mixture of one or more secures bases. This term, coined by Kimberlé Crenshaw, this idea was created to show that an individual could suffer discrimination because of a mix of interrelated attributes that make them disconnected (Berger, Michele \& Kathleen, 9). She and some critical feminists argue that black people suffer a particular form of discrimination due to the interaction of class, gender, and race mostly. One not only suffers because of the race but also gender

\begin{tabular}{ll|ll}
$\mathbf{K}$ & C & AL-KINDI CENTER \\
$\mathbf{R}$ & $\mathbf{D}$ & FOR RESEARCH AN &
\end{tabular} R D DEVELOPMENT Your gateway to world-class research

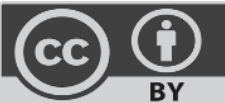

Published by Al-KindiCenter for Research and Development, London, United Kingdom. Copyright (c) the author(s). This open access article is distributed under a Creative Commons Attribution (CC-BY) 4.0 license 
and class. This theory is substantially represented in Toni Morrison's novel The Bluest Eye, which describes how African American women and girls like Pecola not only suffer because of their race but also because of their gender and class. Previous studies have researched how intersectional discrimination is involved in The Bluest Eye to get a deeper understanding of how intersectional categories race, gender, and class all play an integral role in the discrimination of African American people.

ShyamaBhardwa has discussed The Bluest Eye in an article titled "Race and gender in Toni Morrison's The Bluest Eye" how race and gender are used to cause humiliation and discrimination experienced by African American women and how this is portrayed in the novel. Gender and race indicate the agonizing situation under which African Americans stayed in white American society. Sexism, too, was more discriminating and the cause of oppression to African American women who were sexually oppressed by white and black men. They bore discrimination and humiliation with the white and other women of color that were also exploited by their gender. This study reveals how black women, particularly Pecola, Claudia, and Pauline, were exploited by their families and society because of their color. Since the days of slavery, African Americans, regardless of their gender, experienced racism's harsh reality. They bear discrimination and humiliation with white or other color women who are exploited by their gender. (Bhardwa)

Meanwhile, there is a slight distinction between them. Here, the black women, particularly dark-skinned, not only encounter gender humiliation but also class and race discrimination. This study reveals how black women, particularly Pecola, Frieda, Claudia, and Pauline, are exploited by their families and society because of their different appearances and color socially, culturally, and physically. This research supports how the impact of race, class, and gender issues are interrelated to cause discrimination against African American women. Definitely, this research is beneficial for my chapter, even though it did not give an intention to the dilemma of shadism that we are going to adopt through the lens of intersectionality.

In her article entitled, "race and gender in Toni Morrison's The Bluest Eye."(2009), Kathrin Rosenbaum points out how Morrison faces the truth about the intersection of race and gender by discussing how sexism and racism operate in her article and the unpleasant consequences which happen. Gender and race have adversely shaped many people who lived throughout history. Most notably, native African Americans and Americans have been victimized and discriminated against irrespective of their skin color. This study shows how Morrison expounds on the intersection of race and gender by placing race over gender, which means concentrating more on race rather than a gender issue, and how she believes that racism influences gender discrimination even though they are interrelated. On the contrary, my study shows how the issues of race, gender, and other identity aspects are related to each other. Starting from the race issue'shadism' which leads to stand out other identity aspects and affect a person.

An article published by Erna Cahyawatti and Iben Sienna AdeRachman titled "Child Abuse Rooted from Racism in Toni Morrison's The Bluest Eye" of child abuse portrayed in the novel. The Bluest Eye is a conflict between two races, the white people and the black people. This circumstance makes black people suffer from repressive conditions like poverty, lack of education and position, and low salaries. To flee from this situation, they turn to alcoholism and get involved in prostitution. Addiction could make someone lose consciousness and cause violent behaviors such as disturbing those around them, including family, particularly kids, because theyare more likely to be victims of sexual practices and harassment. Prostitution could make a person appear dirty, and little kids become easy targets of sexual assault and harassment. Poverty is also equal to the factors described above because it makes individuals stay under pressure because of lack of money. Though research shows how racism causes poverty, violence, and prostitution, it tends to privilege race over class and gender. Again, this research focuses just on the issues of race and gender in The Bluest Eye. While my research goes into an in-depth detailed analysis of most of the identity aspects such as age, ability, class, education, and other aspect's intersection as a lens of racism acts, making the research more fruitful from all angles.

Alessandro Geary, "Intersectionality of a Poor, Ugly, Black girl", explores how the novel depicts blacks' domination by the existing European standards of beauty and how racism devastates African American women and female children's self-image. This research also shows how the novel, at its core, is about the discrimination bolstered by sexism, racism, and classism influencing black girls in the white supreme America. It also shows how Morrison, at the stage of her literary work, views racism as the only main issue affecting African American people. This study helps to understand how Morrison separates race from gender and race in that it influences both of them to cause discrimination. Alessandro Geary has a significant argument to start within this project because it discusses the issue of the intersectionality of many aspects that black society suffers from, especially female characters. However, the additional and different point of the present research is to discuss the shadism from Geary's perspective, which is intersectionality. This means that any form of racism indeed has a relation or effect from other aspects.

Discrimination based on skin color, also termed shadism, is a form of bias or prejudice in which individuals are treated differently based on the social meanings associated with skin tone or color. The issue of shadism has been present in African American societies for many centuries, becoming clearly outlined during slavery. The multiple shades of black skin originate from the combination of genes leading to slave white masters' sexual assault of African American slaves (Hunter, 2007). Their combined

Page | 223 
race children were still regarded as slaves based on one rule, but they were even given more privileges than their dark-skinned counterparts. Light-skinned slaves were featured as more able and intelligent, were usually offered some educational training form, and performed easier jobs.

In contrast, dark-skinned worked more difficult jobs in the plantation fields. This distinction of families was a deceitful means of dividing society, eliminating their collective identities, and prohibiting communication amongst slave groups so as to avoid escape or rebellion. Shadism plays a considerable role in how it affects intersectionality categories like race, gender, and class. Research has shown that light skin has been connected to European beauty standards, privileges and opportunity, while dark skin has been associated with poverty, inferiority, and ugliness (Kohler, 2).

The prodigy of shadism has influenced and continues to affect communities with complicated and profound histories of racism, colonialism, and what was historically marked as racial interbreeding and miscegenation. The word shadism is modeled on other oppressive beliefs such as racism and is notably used in the US racial contexts. Suchit roots shadism to colonialism in his research article titled "Shadism: Exploring Inequalities within a Historicizing Agenda"(2016). Though many researchers separate the issues of shadism and racism, shadism is equal and is very well fused into the fractures of racism (Dixon \&Telles, 408). Like all racism forms, Shadism elucidates color discrimination with racist ideas by suggesting that the discrimination between light-skinned and dark-skinned people is not due to the oppression of dark-skinned people but the subordination of dark-skinned people.

\section{Analysis}

Quite often, when discussing The Bluest Eye, Toni Morrison addresses the tale that served as a source of motivation for the novel. She remembers while she was at the beginning of elementary school when she was first made wittingly aware of the selfloathing feeling that beauty standards can cause. Sheand a friend had been debating over God's existence and how she believed he wasn't real because after desperately praying for blue eyes for two years, her wish was not granted. Morrison claimed that her friend had an epiphany because she viewed her friend and thought it would have been terrible if God had given her blue eyes. She realized that her friend was so beautiful, which makes her question her looks.

And atten, you don't think in those terms. Somebody is cute, or, you know, whatever, but not beauty. And that was the first time I saw it. She was very dark; she had these wonderful almond eyes, high cheekbones...I mean, you could go on. And she wanted something other. (Morrison)

Many artists during the 1920s and 1930s highlighted that the means to attain the art of white standards politics, which spoke of nationhood and self-determination, was through a common, though varied, Black Aesthetic. Rambsy II and Smethurst describe the concept as the establishment of a system of aesthetic value entrenched in black traditions that the art of the Black Nationalism and African American movement can be formed, evaluated, and studied. Part of the movement's idea was that 'Black is beautiful,' saying that urged African American poets to overturn accepted values and traditional forms and black people to quit viewing themselves through white eyes (Trodd, 645). Morrison has her concerns about this slogan because it shows the probability of people overlooking the facts that black had not usually been pretty and that nobody would remember how agonizing a specific type of internecine racism is. Another concern was that it seems to be not whether black was pretty or not, but with the design, for it to be. According to Williams (2009), some contemporary African American writers began criticizing black societies' perpetuation and acceptance of white values and notions. According to Morrison, when the society adopted the physical beauty concept without adopting it to embrace blackness, assimilation and blackness become probable harmful outcomes, as it happens to The Bluest Eye (Williams, 72).

Other than race problems, gender issues also contribute to her weariness. Morrisons notes that the phrase Black is beautiful was common at that time among African writers of both fiction and non fiction. This idea by Toni Morrison indicates that she may have been showing the reader how the Black-arts-Movement was dominated by men. For example, Bell hooks states that BAM men supported the delegation of women and enforcing of patriarchy. The men believed that women were not supposed to take high positions both at home and in politics. The author believes that no other group in America has had their identity socialized out of existence as black women (Hook, 316).

We can infer that women were rarely recognized as a group during those times. Women are viewed as not important which shows how partiachy was entrenched. In the case of sexism women do not get the same recognition as their white counterparts. Very few authors acknowledged the issue of sexism and how it affected the black women. This is because when black people are talked about the focus tends to be on black men (Hooks, 316).The author words are true in describing how BAM ignores the plight of women and instead focuses on black men. It is important to note that black women identity issues can only be discussed thoroughly and intuitively if the issues of gender, race, and class are analyzed simultaneously. Kimberle Crenshaw reinforces this idea by describing how the concepts of race, gender, class have been misused. 


\section{Shadism and the issues of race, gender, and class in The Bluest Eye's characters}

The issue of shadism has been present in African American societies for many centuries, becoming clearly outlined during slavery. It plays a huge role in how it affects intersectionality categories like race, gender, and class. Research has shown that light skin has been connected to European beauty standards, privileges and opportunity, while dark skin has been associated with poverty, inferiority, and ugliness. Toni Morrison's The Bluest Eye explores the issues of shadism and examines intersectionality categories like race, gender, and class, also their influence on dark-skinned black women, through the main character Pecola Breedlove and other characters.

Through some quotes, we can notice that the issue of shadism is related to racism within the same race and is influenced by other issues like gender and class.

A new girl in school named Maureen Peal. A high-yellow dream child with long brown hair braided into two lynch ropes that hung down her back. She was rich, at least by our standards, as rich as the richest of the white girls, swaddled in comfort and care. The quality of her clothes threatened to derange Frieda and me. (Morrison, 62)

From this passage, we can see that Maureen's status is better than other blacks because of her skin color as light skin girl and class status as a rich family from her clothes and hair made. So, even dark-skinned people will treat her as white because she has some features as white. Here, we can say that racism and differentiation within the same race and between economic and social class intersect in terms of shadism (all of that affect black, not white people). It is a type of oppression between people of the same race, which is a part of shadism as Maureen considers herself different from black people even she is black. Still, because of her class situation ( higher than dark-skinned), she felt superior when she buys ice cream for Pecola. After that, she asked her about seeing her father naked, but Claudia and Frieda started to stick up for Pecola's situation. At that moment, Maureen screamed, "I am cute! And you ugly! Black and ugly e mos" (Morrison, 73). This act of dehumanizingPecola clarifies that she felt superior and uses the same names that other races used to call Pecola. Those issues of the intersectionality of race, class, and beauty standard because light-skinned women are perceived as more attractive and have a higher chance to get married to higher class spouses, while dark-skinned women are regarded as ugly. Thus lowering their self-esteem and also prefer to marry light-skinned men. Society equated light skin with liveability, competency, intelligence, and attractiveness. These issues influence and are intertwined with each other.

Pecola Bladorov is a young African American girl. She lives in a difficult condition environment where she and her society work in seed planting owned by white supremacists. First of all, she is a female; means her gender puts her in a disappointing position toward the patriarchal black male-dominated society. Although less research has concentrated on exploring gender inequality when investigating skin tone effects, some researchers have pointed the impact of skin tone based on gender; many have demonstrated that having light skin is beneficial for African American men and women. Second, she is from a poor family, so economically, her situation as a lower-class girl aggravates the situation. Another thing is her black society will not accept her point of having a blue eye. Thus, show how shadism is a very sensitive issue in African American and its effect on people of color. In addition to that, it influenced by the intersection of race, gender, and class together where she became disappointed because of the oppression from different aspects of identity as Kathy Davis claims," [intersectionality] refers to the interaction between gender, race, and other categories of difference . . . social practices, institutional arrangements, cultural ideologies, and the outcomes of these interactions" (68). From the above, all the race issues cannot be separated from other categories of identity because it influences it.

Pecola is blamed for the bad things that befall her every time. The quote below illustrates this point further when she was talking about the seeds and how it will not matter whatever is bring, explaining that their generation will not change or get off the idea of being controlled "Certain seeds it will not nurture, certain fruit it will not bear, and when the land kills of its own volition, we acquiesce and say the victim had no right to live.

We are wrong, of course, but it doesn't matter. It's too late. At least on the edge of my town, among the garbage and the sunflowers of my town, it's much, much, much too late. (Morrison, 131).

We can notice from this quote that the entire town where Pecola lives is blaming her for the rape and saying that it cannot come from anything; there must have been a reason for that to happen and that it was not because of nothing. Another thing was the case of Cholly when he was having sex with the young girl, and there two white men put the flashlight on him and forced him to continue. He felt this action from white people as a humiliation for him, and he hates the girl as well. So, from this situation, Pecola and Cholly suffered racism from the two white men. We can notice that the colored women suffered from the intersection of race and gender as Crenshaw classified it as 'Structural intersectionality' which refers to "the ways in which the location of women of colour at the intersection of race and gender makes our actual experience of domestic violence, rape, and remedial reform qualitatively different than that of white women" (Crenshaw, 171). The act of shadism is evident when it comes to the 
hate of a black to the colored girl, but it influences by the issues of gender as Pecola's situation with the white, which makes her hate being black and black men, which makes her hating her race (skin color) and her gender.

The society surrounding Pecola affects her, even the children in the school, because she is dark-skinned. As shown below, the light-skinned children are surrounding Pecola and tounting her by shouting 'Black e mo'.

"Bay Boy, Woodrow Cain, Buddy Wilson, Junie Bug-like a necklace of semiprecious stones they surrounded her. Heady with the smell of their own musk, thrilled by the easy power of a majority, they gaily harassed her. "Black e mo. Black e mo. Yadaddsleepsnekked. Black e mo black e moyadadd sleeps nekked. Black e mo..." (Morrison, 43)"

From this quote, "Blackemo" shows that Pecola is blacker than those who participate in that speech are a mixture of light and dark-skinned children. Here, we can notice that the racism and the oppression come even from the same race children who prove that they do not have the same class, social, and racial roots. From this point, Suchit's definition of intra-racial shadism occurs when the same racial group members discriminate against each other based on their skin tone(3). Shadism is a part of the oppression of the same race in terms of class, race, gender, or social hierarchies. In this case, Pecola is being described as blacker and being taunted by the light-skinned children who feel they are more privileged than her. Thus, she underwent discrimination from her own race, which illustrates shadism.

The quote below is a narration by Toni Morrison of the event of Pecola being raped by her drunk father.

He wanted to fuck her-tenderly. But the tenderness would not hold. The tightness of her vagina was more than he could bear. His soul seemed to slip down to his guts and fly out into her, and the gigantic thrust he made into her then provoked the only sound she made-a hollow suck of air in the back of her throat. Like the rapid loss of air from a circus balloon. (Morrison, 100)

When Cholly comes home in a drunken situation, he could not recognize anything around him when Pecola was in the kitchen. She was shocked about his sexual desire and remained silent as he raped her. The rape that Cholly did with his daughter as he is her father and from the same family and race, but not from the same-sex shows discrimination from Cholly, who is also black just like Pecola but doing it with her simply because she is a girl. Additionally, because she is black means that no one will pay attention to her situation. Here, I believe that we can introduce the concept and term "stereotype threat" (Steele and Jeffrey Aronson, 797). In this situation, Pecola accepts the blame in the sense that she is willing to let it go and not pursue it. We can assume that Pecola feels degraded and embarrassed not only from being raped but mainly because of being raped by her father.

From this act, shadism is evident because the discrimination and oppression come from the same race tone (black); but is influenced and intersects by other aspects like sexuality, gender, social and economic class. At first, the concept of sexuality is used verbally because the one who rapes her is her father. However, Pecola is the one who is oppressed, and her father is privileged because he is older, male, and able to do anything as a father. Secondly, because she is a female and especially still young, it makes it easy to do that. Thirdly, her social and economic class, Cholly is her father who is responsible for the family both economically and socially, so he is the provider of everything. All these issues intersect at one point of oppression which leads to shadism. It is not only about race or racism within the same race but also about other issues to make the act of racism appear. In this passage, we notice the existence of the intersection of sexuality, gender, the social and economic class, which leads to saying that shadism can be gendered, be a class issue as well.

\section{Conclusion}

The Bluest Eye presents shadism in a way not done before. The analysis shows that shadism is influenced by race and other aspects of intersectionality such as gender, race, age and ability, and other aspects of identity. Different shades of African American skin were from the mixing of genes as a result of black women being raped by their white settlers. White settlers used the one-drop rule to keep the mixed-race children enslaved. However, the mixed-race children were granted more privileges and were even characterized as smarter than the dark-skinned children. Also, the light-skinned blacks were offered education opportunities and would often work in less strenuous jobs. In the novel, we have different characters who experience different situations in their lives that change them significantly. Maureen is light-skinned and is treated differently from other people due to her skin color. Pecola, on the other hand, has dark skin and is fascinated by Maureen, who believes that she is beautiful. Maureen discriminates against Pecola by calling her ugly, presumably due to her skin tone. She then proceeds to label herself cute. This event forces Pecola to consider having blue eyes, which she thinks will make her loved by everyone. These events present an example of how racism within the same race had similar ideals to racism between whites and blacks. Shadism influenced the way dark-skinned blacks lived and the opportunities they got. It condemned them to low points in life as they 
were at their fellow light-skinned blacks' mercies. This paper has shown the impact of shadism on black people, especially women of color, by analyzing the novel's main characters and events.

Shadism influences other issues such as gender, race, age and ability, and other aspects of identity, where they intersect at one point that shows shadism. The intersectionality theory that I adopt helps a lot identify and deal with the problem of shadism from different angles to clarify the relationship of racism racial discrimination (shadism in this case) to most components of characters' identity. Again, this indicates the effects of sexism, ageism, class, and racism on women, especially women.

\section{References}

[1] Berger, M. T. Kathleen Guidroz, eds. (2009). The Intersectional Approach: Transforming the Academy through Race, Class, and Gender.

[2] Berger, M. T., \&Guidroz, K. (Eds.). (2010). The intersectional approach: Transforming the academy through race, class, and gender. Univ of North Carolina Press.

[3] Bhardwaj, Shyama. (2017). "Race and gender in Toni Morrison's The Bluest Eye": National Journal of Multidisciplinary Research and Development, Singhania University, Rajasthan, India, 2(3), 338-341.Retrieved from http://www.nationaljournals.com/download/209/2-3147-837.pdf

[4] Bloom, H. (Ed.). (2007). Toni Morrison's the bluest eye. Infobase Publishing.

[5] Caldwell, P. M. (1991). A Hair Piece: Perspectives on the Intersection of Race and Gender. Duke Law Journal, 1991(2), 365-396. https://doi.org/10.2307/1372731

[6] Cormier-Hamilton, P. (1994). Black naturalism and Toni Morrison: The journey away from self-love in the bluest eye. Melus, 19(4), $109-127$. https://doi.org/10.2307/468206

[7] Crenshaw, K. (2002). Background paper for the expert meeting on the gender-related aspects of race discrimination. RevistaEstudosFeministas, 10(1), 171-188. http://dx.doi.org/10.1590/S0104-026X2002000100011

[8] Crenshaw, K. (2005). Mapping the Margins: Intersectionality, Identity Politics, and Violence against Women of Color (1994). In R. K. Bergen, J. L. Edleson, \& C. M. Renzetti, Violence against women: Classic papers (p. 282-313). Pearson Education New Zealand.

[9] Dittmar, L. (1990, January). Will the Circle Be Unbroken?" The Politics of Form in" The Bluest Eye. In Novel: A Forum on Fiction,23(2), 137155). Duke University Press. https://doi.org/10.2307/1345735

[10] Dixon, A. R., \&Telles, E. E. (2017). Skin color and colorism: Global research, concepts, and measurement. Annual Review of Sociology, 43, 405-424. https://doi.org/10.1146/annurev-soc-060116-053315

[11] Geary, A. (2019)"The Intersectionality of a "Poor, Ugly, Black Girl": Literary Analysis. http://exegeses.web.unc.edu/2017/12/theintersectionality-of-a-poor-ugly-black-girl/

[12] Hill, M. E. (2002). Skin color and the perception of attractiveness among African Americans: Does gender make a difference? Social psychology quarterly, 77-91.https://doi.org/10.2307/3090169

[13] Hooks, B. (1996). Killing rage: Ending racism. Journal of Leisure Research, 28(4), 316.

[14] Hunter, M. (2007). The persistent problem of colorism: Skin tone, status, and inequality. Sociology compass, 1(1), $237-254$. https://doi.org/10.1111/j.1751-9020.2007.00006.x

[15] Kohler, P. (2006). Realizations of Black Aesthetic in Toni Morrison's The Bluest Eye [Master's thesis, Tampere University]. Tampere University. http://urn.fi/urn:nbn:fi:uta-1-15521

[16] Massey, D. S., Charles, C. Z., Fischer, M. J., \& Lundy, G. (2003). The source of the river: The social origins of freshmen at America's selective colleges and universities (Vol. 36). Princeton University Press.

[17] Morrison, T. (1993). Playing in the dark: Whiteness and the literary imagination. New York: Vintage.

[18] Morrison, T., \& Frankel, H. (1970). The Bluest Eye. New Yorker.

[19] Murguia, E., \&Telles, E. E. (1996). Phenotype and schooling among Mexican Americans. Sociology of Education, 276289.https://doi.org/10.2307/2112715

[20] Neal, L. (1994). The black arts movement (pp. 184-198). Duke University Press.

[21] Rosenbaum, K. (2015). Race and Gender in Toni Morrison's "The Bluest Eye". GRIN Verlag.

[22] Steele, C. M., \& Aronson, J. (1995). Stereotype threat and the intellectual test performance of African Americans. Journal of personality and social psychology, 69(5), 797.https://doi.org/10.1037/0022-3514.69.5.797

[23] Suchit, C. R. (2016). Shadeism: Exploring Inequalities Within a Historicizing Agenda. [Master Thesis, York University]. York University Repository. http://hdl.handle.net/10315/32664

[24] Williams, D. A. (2009). Contemporary African American Women Writers. The Cambridge Companion to African American Women's Literature, 71-86. 